\title{
O EXTERMÍNIO COMO CORREÇÃO: A NECROPOLÍTICA E 0 ROMANCE ASSIM NA TERRA COMO EMBAIXO DA TERRA, DE ANA PAULA MAIA
}

\section{EXTERMINATION AS CORRECTION: THE NECROPOLITICS AND THE ROMANCE ASSIM NA TERRA COMO EMBAIXO DA TERRA, BY ANA PAULA MAIA}

\author{
Maria Perla Araújo Morais ${ }^{1}$ \\ [https://orcid.org/0000-0002-9860-1706] \\ DOI: 10.30612/raido.v14i35.11916
}

\begin{abstract}
RESUMO: Neste artigo, queremos discutir o romance Assim na terra como embaixo da terra (2017), de Ana Paula Maia. A obra nos convida a pensar no sistema penal numa aparente situaçấo-limite, em que presos săo assassinados pelo administrador de uma Colônia Penal.Acontece que esse cenário năo é estranho ao atualEstado brasileiro, tendo em vista o encarceramento em massa e o recrudescimento das políticas de extermínio de certos grupos sociais e étnico-raciais sob o pretexto da contençấo da violência. Essas práticas de extermínio podem ser entendidas a partir da necropolítica, um tipo de dinâmica em que o Estado gerencia a morte para a garantia da ordem pública. Essas ideias săo confrontadas pelo romance, fazendo-nos questionar se o sistema penal náo é uma das instituiçôes que legitimam a necropolítica a fim de silenciar os problemas econômicos e sociais.
\end{abstract}

Palavras-chave: Biopoder; necropolítica; Estado Suicidário; sistema penal; Ana Paula Maia

ABSTRACT: In this article, we want to discuss the novel Assim na terra como embaixo da terra (2017), by Ana Paula Maia. The work invites us to think about the penal system in an apparent extreme situation, in which prisoners are murdered by the administrator of a Penal Colony. It turns out that this scenario is not foreign to the current Brazilian State, in view of the mass incarceration and the resurgence of policies for exterminating certain social and ethnic-racial groups under the pretext of violence control. These extermination practices can be understood from the necropolitics, a type of dynamic in which the State manages death to guarantee public order. These ideas are confronted by the novel, making us question whether the penal system is not one of the institutions that legitimize necropolitics in order to silence economic and social problems.

Keywords: Biopower; necropolitics; Suicidal State; penal system; Ana Paula Maia

1 Doutora em Literatura Comparada pela UFF. Professora de Literatura Brasileira do Curso de Letras e do Mestrado em Letras da UFT. 


\section{INTRODUÇÃO}

O título do romance da escritora brasileira Ana Paula Maia Assim na terra como embaixo da terra enfatiza uma situaçăo de permanência em lugares distintos. Tanto na terra como embaixo dela há algo que se mantém, nos dando a impressâo de uma fatalidade da qual năo é possível escapar. A permanência, no entanto, nem sempre é algo negativo, uma vez que existem situaçōes em que ela pode ser fundamental para a própria sobrevivência. Assim, quando lemos o romance, percebemos a permanência associada a um ciclo de repetiçóes da opressấo e também da resistência, instituindo a vida dentro de uma constante luta.

O romance conta a história de um grupo de detentos dentro de uma colônia penal administrada pelo personagem Melquíades e por seu ajudante, Taborda. Os presos náo sabem por que estăo ali e o que significa ser transferido para a Colônia Penal, já que todos cumpriam pena em outro lugar. Na Colônia, estăo submetidos aos caprichos e vontades do administrador, que adquirira o gosto de matar os presos numa espécie de caçada. Alguns sabem que, se náo elaborarem um plano de fuga, nunca sairấo daquela Colônia vivos, como Bronco Gil, Pablo e Valdênio. Numa das últimas caçadas, Pablo consegue escapar de ser morto e, na procura por ele, Melquíades sofre um acidente, perdendo a memória. Quando Heitor, o novo oficial, chega à Colônia para desativá-la, só há Bronco Gil, Valdênio e Taborda lá. O oficial traz um novo preso: Melquíades, que perdera a memória e estava com a roupa de preso, uma vez que Pablo tinha trocado o seu uniforme com o do administrador. Aos poucos, Melquíades consegue se lembrar de quem era e começa a caçar os que estăo dentro da prisâo, inclusive o novo oficial.

A partir do romance, percebemos a manutençăo de dinâmicas em relaçăo a como lidar com aqueles que desobedecem aos princípios da lei ou que sáo vistos como corpos selvagens por uma sociedade que abdicou de pensar nos impactos sociais dos projetos econômicos. Essa permanência de dinâmicas de repressăo se dá em espaços distintos, mas também em tempos diversos, uma vez que o romance sugere uma continuidade de práticas de correçăo que săo chanceladas para grupos năo-hegemônicos desde o Brasil colônia. Podemos afirmar que a obra reflete sobre a permanência de formas injustas de praticar a justiça e como resistir a essa estrutura.

Essas formas têm a ver com as estratégias conjugadas da biopolítica e necropolítica que fomentam as políticas do Estado. Assim, a partir da ideia da promoçáo da vida, proporcionada pelo biopoder e defendida pelo Estado moderno, aposta-se na narrativa da emancipaçâo humana. Quanto mais disciplinar e regulamentador for o Estado, mais próximo ele estará da criaçăo dos sujeitos emancipados. Entretanto, quando observamos os grupos que sofrem as sançôes dessa sociedade disciplinar, constatamos a açâo de um componente étnico-racial produzindo desigualdades. Se atravessarmos o biopoder pelo racismo e pelo fascismo das políticas neoliberais, veremos outras forças atuando para que a sociedade que visa à emancipaçăo igualmente produza desigualdades e, portanto, grupos que serăo vistos como improdutivos, ociosos e desordeiros permanentemente. $O$ contingente de excluídos é, ao mesmo tempo, nesse entrecruzamento de narrativas em que estamos, causa e consequência das formas como organizamos a vida social.

Por isso, é possível ver a narrativa do biopoder sob um outro viés: nâo o que fomenta a vida, mas o que gerencia a morte de amplos grupos de nossa populaçăo. Nesse 
sentido, o sistema penal corrobora com esse gerenciamento uma vez que năo visa à correçấo, muito menos a inclusăo, mas sim ao extermínio ou exclusăo.

O romance de Ana Paula Maia movimenta esse problema e nos faz pensar se, ao contrário do seu sentido hegemônico, o sistema penal năo pode ser pensado intrinsecamente relacionado ao sistema econômico e social brasileiro, funcionando como um dispositivo para silenciar a desigualdade e gerenciar a escassez dentro de um modelo de sociedade acumulativo de capital. Assim, a Colônia Penal no romance descortina a lei como um lugar vazio dentro da narrativa progressista e emancipatória, mostrando que é mais um dispositivo da gerência das desigualdades do que um aparato para emancipaçáo do homem.

\section{BIOPODER, NECROPOLÍTICA E SOCIEDADE}

Para Foucault, o Estado moderno é perpassado por um sistema de direito, cuja origem encontra-se na soberania (o "poder de deixar viver" e o "poder de deixar morrer"). Nesse sistema, convivem mecanismos disciplinadores e regulamentadores. O primeiro normaliza o corpo individual e encontra na morte a expressăo mais fiel do poder; o segundo se refere ao controle de populaçóes a partir da regulamentaçăo, numa forma de garantia da longevidade. Trata-se de ver o poder sobre o controle da vida ou o biopoder: "Portanto, estamos num poder que se incumbiu tanto do corpo quanto da vida, ou que se incumbiu, se vocês preferirem, da vida em geral com o pólo do corpo e o pólo da populaçăo." (FOUCAULT, 2005, p.302)

Acontece que, embora o poder regulador tenha como objetivo o prolongamento da vida, como dentro dele o exercício da morte é permitido? A resposta encontra-se no fato de os Estados modernos operarem com o racismo, que produz uma fragmentaçáo biológica dentro dos grupos, instituindo os corpos cuja morte năo é reclamada:

Com efeito, que é o racismo? É, primeiro, o meio de introduzir afinal, nesse domínio da vida de que o poder se incumbiu, um corte: o corte entre o que deve viver e o que deve morrer. No contínuo biológico da espécie humana, o aparecimento das raças, a distinçăo das raças, a hierarquia das raças, a qualificaçăo de certas raças como boas e de outras, ao contrário, como inferiores, tudo isso vai ser uma maneira de fragmentar esse campo do biológico de que o poder se incumbiu; uma maneira de defasar, no interior da populaçăo, uns grupos em relaçăo aos outros. (FOUCAULT, 2005, p.304)

Isso explica o paradoxo no qual nos encontramos quando percebemos que o mesmo Estado que se serve de um aparato regulamentador da vida para alguns grupos (sistema de justiça, saúde, educaçâo, por exemplo) promove um verdadeiro genocídio de outros. O racismo, no entanto, se encaixa perfeitamente dentro dos cálculos do biopoder ao promover uma situaçấo de guerra travestida de confronto biológico, em que para que um grupo viva outro tenha que morrer:

De uma parte, de fato, o racismo vai permitir estabelecer, entre a minha vida e a morte do outro, uma relaçâo que nâo é uma relaçấo militar e guerreira de enfrentamento, mas uma relaçăo do tipo biológico: "quanto mais as espécies inferiores tenderem a desaparecer, quanto mais os indivíduos anormais forem eliminados, menos degenerados haverá em relaçâo a espécie, mais eu - nâo enquanto individuo mas enquanto espécie- viverei, mais forte serei, mais vigoroso serei, mais 
poderei proliferar". A morte do outro nâo é simplesmente a minha vida, na medida em que seria minha segurança pessoal; a morte do outro, a morte da raça ruim, da raça inferior (ou do degenerado, ou do anormal), é o que vai deixar a vida em geral mais sadia; mais sadia e mais pura. (FOUCAULT, 2005, p. 305)

Garantida pelo biopoder como uma forma de manter a vitória da espécie, a morte năo só é permitida como desejada. Assim, a aceitaçăo da morte de amplos contingentes populacionais está dentro da narrativa do biopoder, porque ele, em sua promoçáo do corpo social saudável, localiza no "outro" uma degenerescência que contamina e impede a sociedade de rumar para a sua emancipaçấo. A eliminaçăo do "outro" no biopoder é uma política que coexiste com os mecanismos que regulam e normatizam a fim da longevidade da vida.

Dentro de um Estado como esse, o sistema de justiça se organiza atravessado pelo racismo e, portanto, garantirá a proteçâo da vida de alguns grupos e aceitará a eliminaçâo de outros. Essa política de extermínio em nome da "vida" será exercida pelos mecanismos criados dentro dos Estados modernos para a proteçấ, como o sistema penal. Mas assumirá nas colônias formas tăo extremas que nos fará pensar se, no contemporâneo, as narrativas de autonomia do sujeito pelo biopoder năo estariam engendrando políticas de destruiçâo dos corpos e das populaçôes, uma submissâo distinta da vida à morte ou a necropolítica, como conceitua o filósofo camaronês Achille Mbembe: "A ocupaçấo colonial tardia difere em muitos aspectos da primeira ocupaçâo moderna, particularmente em sua combinaçâo entre o disciplinar, a biopolítica e a necropolítica." (MBEMBE, 2018, p. 41)

De acordo com Mbembe, nas colônias, a necropolítica teria sido tăo bem-sucedida que sua dinâmica pode explicar até a possibilidade da ascensáo do nazismo. As colônias seriam lugares onde o estado de exceçâo está em pleno funcionamento em nome da civilizaçấo. Acredita-se que, nas colônias, năo havia um projeto autóctone para a criaçấo de sujeitos autônomos (cidadáo), o que fez com que a vida do outro fosse comparada à vida animal (o selvagem), estratégia que ratifica qualquer prática da violência e retira qualquer culpa no extermínio. O colonialismo expôs o limite da razăo, do universal e da moralidade, uma vez que os territórios eram pensados como aqueles em que a guerra pode ser mobilizada sem fim, sob o pretexto de se acabar com o inimigo, a desordem e o criminoso.

Dentro dos territórios coloniais, dinâmicas sociais chancelavam essa necropolítica, como, por exemplo, "a fragmentaçáo territorial, o acesso proibido a certas zonas e a expansâo de assentamentos." (MBEMBE, 2018, p.43). Essas dinâmicas nos permitem observar a "política de verticalidade" a serviço da necropolítica:

Sob condiçōes de soberania vertical e ocupaçăo colonial fragmentada, comunidades sâo separadas segundo um eixo de ordenadas. Isso conduz a uma proliferaçấo dos espaços de violência. Os campos de batalha nâo estăo localizados exclusivamente na superfície da terra. Assim como o espaço aéreo, o subsolo também é transformado em zona de conflito. Nâo há continuidade entre a terra e o céu. Até mesmo os limites no espaço aéreo dividem-se entre as camadas inferiores e superiores. Em todo lugar, o simbolismo do topo (quem se encontra no topo) é reiterado. (MBEMBE, 2018, p.46)

A verticalidade acaba criando năo só divisōes espaciais como hierarquias, mostrando que todo o território dentro das colônias está a serviço da necropolítica. Em 
outro momento, Memmi já tinha nos alertado que na colônia tudo aparece colonizado (MEMMI, 1977), numa forma de pensar territórios e subjetividades expostos a maneira de valorar centrada no colonialismo.

Podemos ver o reflexo dessa questáo em, pelo menos, três aspectos que se relacionam com o romance de Ana Paula Maia: o primeiro diz respeito a como a necropolítica nos ajuda a pensar nas territorialidades das ex-colônias, como o Brasil; o segundo se refere à semelhança da passagem de Mbembe ao título do romance Assim na terra como embaixo da terra e o terceiro é sobre como a política da verticalidade é extremamente produtiva, no contemporâneo, em outras áreas que, igualmente ao sistema penal, regulam e normatizam a vida, como o sistema de saúde pública.

Sobre a primeira questăo, temos visto que, de fato, o necropoder no Brasil institui territórios onde a guerra é permanente a partir de uma narrativa que olha para alguns grupos e áreas como territorialidades inimigas da ordem e da segurança pública. Invariavelmente essa política de submissăo da vida à morte é atravessada pelo racismo, uma vez que a maioria da populaçấo que habita esses territórios săo negros. Nos EUA, por exemplo, temos a narrativa da guerra às drogas, fazendo com que a populaçâo afro-americana seja discriminada ou exterminada em nome da paz:

Na Guerra à Drogas, o inimigo é definido racialmente. Os métodos de segurança públicas (...) têm sido empregados quase que exclusivamente em comunidades năo brancas pobres, resultando em números impressionantes de afro-americanos e latinos ocupando as prisóes dos Estados Unidos todos os anos. Os soldados da Guerra às drogas nos dizem que o inimigo nessa guerra é uma coisa - as drogas - e năo um grupo de pessoas, mas os fatos provam o contrário. (ALEXANDER, 2017, p. 156)

No Brasil, temos "pacificaçōes" com as UPPs (Unidades de Polícia Pacificadora) em comunidades periféricas, em que também, em nome do fim da violência urbana, territórios sáo ocupados permanentemente pelo aparato da polícia militar. Recentemente, a lei 13.964/19, chamada de "pacote anticrime", foi sancionada e já está em vigor desde 23 de janeiro de 2020. Essa lei faz parte daquelas políticas que acreditam na necessidade de aumentar a eficácia do aparato penal para a diminuiçáo dos crimes e corrupçâo. Vemos que esse pacote conta com aceitaçâo de parte da sociedade, permitindo mesmo que políticos que o defendam se elejam com essa plataforma, ao mesmo tempo em que reduzem os direitos dos cidadăos. Alinhado ao discurso da defesa da ordem ou da defesa da vida concebida dentro dos cálculos do poder, o Estado elabora políticas que visam ao extermínio de boa parte da populaçăo. Delegando os problemas da "desordem" ao argumento da falta de civilidade e progresso de vários grupos e visualizando algumas territorialidades como "terra arrasada", o Estado brasileiro pode ser visto dentro da necropolítica. Alinha-se a essa necropolítica também a insatisfaçăo de parte da populaçăo que, diante das políticas neoliberais, resistem ao discurso de justiça social, apostando na xenofobia, moralismo e manutençăo das tradicionais hierarquias de classe, raça e gênero.

O segundo aspecto diz respeito à semelhança do que Achille Mbembe chama de política da verticalidade, adotada dentro das colônias, e o título do romance de Ana Paula Maia. Se o título nos fala da permanência de algo na terra e embaixo dela, é porque todo o território encontra-se impregnado de uma lógica da qual é difícil se esconder. As territorialidades săo pensadas dentro dessa forma, instituindo zonas de conflitos e o topo onde estăo os dispositivos de controle. A permanência dessa política da verticalidade 
nos diz, ainda, que, mesmo na terra, há o subsolo, numa forma de expor que a dinâmica hierárquica e colonial náo deixa nenhum espaço e tempo a salvo. Sua reproduçáo ao infinito, como um fractal auto-semelhante ou um vírus auto-replicante, năo faz pensarmos na divisăo entre o céu e o inferno ou vida e morte, mas numa política de morte infinita que sobrevive em todos os tempos e espaços. A sociedade organizada dessa forma năo é diferente de um estado de guerra permanente.

Por fim e como consequência da necropolitica, podemos pensar que essa estratégia da verticalidade é uma forma aceita como legítima em todas as instituiçōes do Estado brasileiro e foi aventada recentemente, durante a pandemia da COVID-19, com o nome de "isolamento vertical", uma estratégia a fim de diminuir os impactos da doença na economia. Diante da pandemia, uma das primeiras medidas adotadas pelo Estado brasileiro foi o isolamento social, que consistia no fechamento do comércio năo essencial a fim de evitar a disseminaçâo do coronavírus, muito letal e de fácil propagaçâo. Ao contrário desse isolamento social, em que pessoas de diferentes idades estariam resguardadas em seus lares, o vertical propóe que só alguns grupos fiquem em seus lares (os idosos e os que possuam comorbidades). É importante assinalar que a OMS recomendou o isolamento social como medida para conter a rápida disseminaçâo do coronavírus a fim de que os sistemas de saúdes dos países năo entrassem em colapso. O relatório de alguns professores da UFMG "Isolamento social vertical é ineficaz para conter a pandemia COVID-19 (coronavírus)" informa que a verticalidade é quase tăo ineficaz quanto a inexistência de isolamento:

O isolamento vertical com reduçăo de 15 vezes no contato social faz com que rapidamente um grande número de infectados (cerca de 200 mil) surja na faixa etária de 60+ anos, provocando um enorme fluxo de pacientes necessitando de internaçáo hospitalar imediata, sem que existam leitos suficientes na rede hospitalar de Belo Horizonte.

O isolamento horizontal (15X) proposto, em comparaçăo, faz com que a epidemia só se manifeste, e de maneira bastante reduzida, após 16 meses de seu início, desafogando a rede hospitalar, reduzindo o número de vítimas fatais, e ainda permitindo que futuras intervençóes possam ocorrer posteriormente (vacinaçăo, novos medicamentos, etc.). (UFMG, 2020, p.9)

A OMS é uma das organizaçôes cuja a existência só é possível dentro das práticas do biopoder. Como defendemos que, no caso brasileiro, além do biopoder, temos provas suficientes para acreditar que opera em nosso Estado as práticas da necropolítica, a defesa do isolamento vertical é totalmente compatível e sintomática. Trata-se de ver a sociedade imersa numa guerra cuja vitória se daria pelo sacrifício do outro o que inclui também o suicídio do mesmo. Agora, pessoas com comorbidades e idosos, pela faixa etária e pelas doenças preexistentes, também estăo inclusos no cálculo do biopoder e podem ser corpos descartáveis, uma vez que o isolamento vertical desse grupo náo é suficiente para que se evite a propagaçăo da doença. Além disso, só resguardar essa populaçăo năo é uma política de enfrentamento à pandemia, porque desconsidera que, por problemas socio-econômicos, as populaçōes mais pobres estarăo mais expostas à doença, ou seja, é contar com a morte desse grupo mais uma vez.

Entăo, ao contrário do que o isolamento vertical propaga, náo estaríamos defendendo os grupos vulneráveis, mas os condenando à própria sorte. Aqui, veríamos o 
Estado nâo só atravessado pelo racismo, que lhe é estrutural, mas pela crise de políticas neoliberais que agora devem avançar sobre mais corpos. Dentro das narrativas do biopoder e da necropolítica, esse avanço deixa explícito que, para se manter a "saúde" dos Estados, é preciso tomar medidas năo contra o corpo estranho, a COVID-19, mas contra o mesmo corpo, eliminando as partes menos produtivas e aqueles corpos descartáveis. Esse tipo de prática propóe a morte de vários corpos, mas, em última instância, anuncia o próprio fim do Estado como narrativa moderna:

O Estado suicidário consegue fazer da revolta contra o Estado injusto, contra as autoridades que nos excluíram, o ritual de liquidaçăo de si em nome da crença na vontade soberana e na preservaçáo de uma liderança que deve encenar seu ritual de onipotência mesmo quando já está claro como o sol sua impotência miserável. Se o fascismo sempre foi uma contrarrevoluçăo preventiva, náo esqueçamos que sempre soube transformar a festa da revoluçáo em um ritual inexorável de auto-imolaçáo sacrificial. Fazer o desejo de transformaçâo e diferença conjugar a gramática do sacrifício da auto-destruiçăo: essa sempre foi a equaçăo libidinal que funda o Estado suicidário. (SAFLATLE, 2020, s.p.)

Como nenhuma territorialidade está a salvo dentro desse Estado Suicidário, instituir a verticalidade é só uma expressăo do poder, quando, na realidade, o que se pede é o sacrifício de qualquer um, a depender de seu grau de vulnerabilidade. A lógica, portanto, é inversa: quando mais vulnerável for, mas exposto a política da morte promovida pelo Estado. O isolamento vertical institui um topo e sua periferia que, diferentemente do que esse tipo de isolamento prega, se trata apenas de uma expressăo do poder, uma organizaçâo espacial que nâo enfrenta o problema, mas que o dissimula numa metáfora, numa disposiçâo muito bem-sucedida dentro de ex-colônias.

Se fizemos essa incursăo pelo biopoder e necropolítica, é porque acreditamos que a sociedade se organiza de forma a náo observar os custos sociais das desigualdades econômicas. Enquanto năo se atentar para isso, continuaremos apoiando e fortalecendo os aparelhos de controle social que se apresentam como fortalecedores de políticas da vida, ao mesmo tempo em que se vinculam intimamente a políticas da morte.

\section{NECROPOLÍTICA DENTRO DA COLÔNIA}

Ana Paula Maia é escritora, roteirista e duas vezes vencedora do Prêmio SP de Literatura pelos romances Assim na terra com embaixo da terra (2017) e Enterre seus mortos (2018). Sua escrita é direta, ágil; seus enredos, dinâmicos, com uma especial atençâo para descrever ambientes cruéis e violentos, onde năo poderia entrar a nâo ser pela via ficcional: "Săo lugares especificamente para homens. Quando eles entram, eu posso entrar com eles. Năo sou eles, entro com eles". (MAIA apud GRÜNNAGELL, 2015, p. 355). Ao descrever esses ambientes, pontua as relaçôes humanas, as críticas às instituiçóes, o confronto com a morte, as distintas situaçôes de opressôes, oferecendo-nos um importante retrato da complexidade da sociedade contemporânea.

Quando lemos o romance Assim na terra como embaixo da terra, encontramos uma dinâmica que se repete ao longo do texto: o questionamento da maneira hegemônica de se ver a instituiçăo penal. Esse questionamento se dá a partir mesmo da história, mas também por causa de pequenos detalhes e personagens. Assim, sob a imagem da 
proteçăo, que perpassa veloz na narrativa, vemos a alegoria das ruínas dos projetos de emancipaçấo, como o sistema penal. A prisâo, como confinamento que leva à correçâo, aparece como uma construçăo chamada Colônia Penal que se encontra bem distante da cidade e numa regiăo extremamente árida. Para lá săo levados vários presidiários, como Bronco Gil, Valdênio e Pablo, que sâo vigiados pelo administrador do local, Melquíades, e um agente penitenciário, Taborda. Os presos năo sabem, ao certo, por que estấo ali, mas, aos poucos, văo descobrindo que estar na Colônia equivale a uma sentença de morte.

A forma-prisāo, de acordo com Foucault, é, antes de tudo, uma "forma social", ou seja, uma forma "segundo a qual o poder é exercido no interior de uma sociedade - a maneira como ele extrai o saber de que precisa para se exercer e a maneira como, a partir desse saber, ele vai distribuir ordens e prescriçōes" (FOUCAULT, 2015, p. 206). Assim, a prisáo só faz sentido numa sociedade que aceita essa forma de saber e poder. Para que a forma-prisăo funcione, ela tem que atravessar nossas relaçóes sociais, estando presente nas instituiçôes que nos cercam e nos definem: religiăo, família, Estado, profissăo. A forma-prisâo, como forma social, compōe aquela série de dispositivos do sistema disciplinar e regulador que explicam sociedades como a nossa, nos fazendo crer que a privaçáo do convívio leva à correçăo e, consequentemente, à proteçáo. Em última instância, a prisăo seria uma forma de gerir o tempo e corpos daqueles que náo se submetem ao tempo do trabalho, numa maneira de manter o sequestro das subjetividades, uma alienaçấo necessária para a manutençăo dos meios de produçăo:

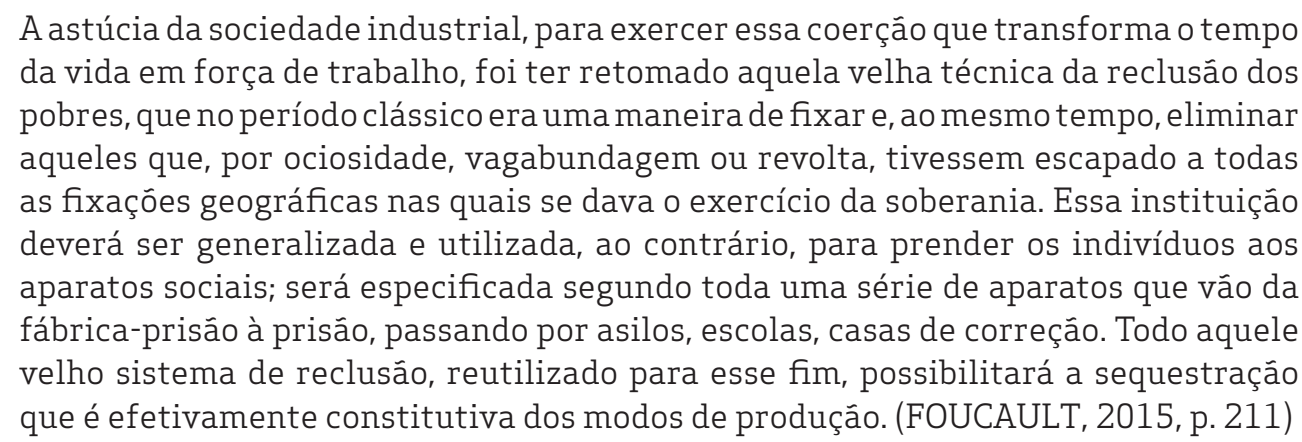

Como é uma forma social aceita, a forma-prisăo demonstra, ainda, que o sistema disciplinar retira da vida qualquer possibilidade de ineditismo, nos prendendo a uma série de aparelhos regulatórios que barganham com a sociedade a ordem como promessa do sujeito emancipado, da liberdade individual ou do pleno usufruto da propriedade privada.

Sobre esse aspecto, no romance de Ana Paula Maia, temos o personagem Melquíades que defende o sistema năo só no seu discurso, mas também nos seus atos. Na história, todos acreditam que Melquíades enlouquecera porque repete açôes e diálogos e mata os presos como se estivesse praticando uma caçada de animal. Entretanto, Melquíades é o resultado mais pleno do sistema, ou seja, é o sistema penal em sua plenitude de açăo. Seu comportamento só pode ser assim compreendido quando considerarmos que todas as açóes desse sistema năo fazem nenhum sentido, sendo apenas uma expressáo do poder. Vejamos uma das primeiras cenas do romance em que encontramos Valdênio, preso que cozinhava na Colônia, numa espécie de diálogo-interrogatório com Melquíades: 
- Pois năo, senhor?

- Valdênio, o que temos para o almoço?

- Galinha, senhor.

- De novo? [...]

- Eu estava pensando, Valdênio, podíamos deixar o leitáozinho para o dia em que o oficial chegar. [...]

- Como o senhor achar melhor. [...]

-Estou certo, Valdênio, que você fará o melhor leităo assado de todo este maldito lugar.

-Vou me esforçar, senhor. [...]

Solta os ombros de Valdênio com a mesma intensidade com que os agarrou, e este chega a perder o equilíbrio, mas, com a ajuda da bengala, novamente encontra o eixo para se firmar.

-Eu diria também que devemos ter um pouco de música aqui, năo acha? Pablo ainda toca aquela gaita?

- O senhor confiscou a gaita.

-Confisquei? Verdade?

Melquíades enruga a testa e se questiona sobre o confisco da gaita de Pablo.

- E você, por acaso, sabe onde a coloquei?

- O senhor jogou do outro lado do muro.

- Joguei? - espalma a máo contra o próprio peito, admirado de sua conduta. - Quando foi isso?

- Semana passada.

Melquíades caminha ardiloso até bem próximo de Valdênio, como se surrupiasse os pensamentos do homem.

- E você saberia me dizer o motivo de eu ter confiscado a gaita?

Valdênio mantém os olhos baixos, fixos em sua perna aleijada. Náo sabe se diz a verdade ou se responde apenas năo saber nada.

-Se o senhor confiscou, teve suas razóes, senhor.

- Ah, muito bem. Boa resposta. Evidentemente eu tive os meus motivos e gostaria de saber: você concorda com os meus motivos?

Valdênio permanece cabisbaixo.

-Desculpa, senhor. Eu só trabalho na cozinha, năo entendo nada de leis.

-Năo falo de leis, homem, falo de justiça. Pablo desacatou a minha ordem. Era necessária uma puniçấo, năo concorda?

-Sim, senhor - responde entre os dentes e com um engulho na garganta.

Melquíades posiciona-se na frente de Valdênio. Contrai o rosto e tensiona os olhos enquanto o investiga minunciosamente, sem tocá-lo, apenas o farejando. [...]

- O que temos hoje para o almoço?

- Galinha.

- Outra vez? Vou acabar criando penas. E o leităozinho?

- O senhor disse que quer assar o leităo quando o oficial chegar. (MAIA, 2020, pp. 11-14) 
A passagem é extensa, mas apresenta vários aspectos relativos à forma-prisăo, presentes nas açōes de Melquíades, mostrando que seu comportamento năo pode ser confundido com uma patologia, mas sim com a plenitude do sistema. A passagem começa e termina com o mesmo questionamento: Melquíades perguntando sobre a comida do almoço e discutindo o leităo como cardápio para o oficial que chegaria na Colônia. Essa repetiçăo na fala pode sugerir que Melquíades está com algum problema de memória, entretanto vemos que, pelas perguntas dispensadas, ele guarda detalhes do que faz com os presos. Sua fala diz respeito à forma-prisăo ("Nâo falo de leis, homem, falo de justiça. Pablo desacatou a minha ordem. Era necessária uma puniçăo, năo concorda?"), que esvai o inédito o esvaziando de sentido, e se concentra no repetitivo, como uma maneira de se preocupar apenas com o que é necessário para a manutençâo daquele lugar: a ordenaçấo e a duplicaçâo do discurso. A forma-prisâo precisa de recursividade, ou seja, ela precisa da repetiçăo para existir, porque nela náo há espaço para o inesperado, o inédito, o inaugural, por isso custa-nos classificar a passagem como um diálogo, uma vez que Melquíades só quer escutar sua própria fala ou aquilo que, na fala de Valdênio, seja uma afirmaçáo de si. Valdênio, para sobreviver, desliza por essas práticas de Melquíades; desenvolve uma, por assim dizer, terceira via, metaforizada na própria bengala que o segura, apoia e o impede de cair nas artimanhas de Melquíades. Responde dentro da lógica do interrogatório, porque sabe que, dentro da prisăo, tudo é prisâo. Essa forma contamina e produz todas as relaçóes sociais ali dentro. As relaçóes estăo dentro, portanto, das políticas das verticalidades.

Melquíades năo quer respostas; ele quer apenas se ver refletido na fala de Valdênio ( "Se o senhor confiscou, teve suas razóes, senhor."), mostrando que o poder é um exercício vazio de sentido a năo ser se autoafirmar constantemente. Quando é enfático para obter uma resposta dentro do binarismo do sim e do nâo, Valdênio lhe responde diretamente, mas deixa registrado a sua consciência de que, ali dentro, justiça tem a ver com o que quem tem poder pensa (-Sim, senhor - responde entre os dentes e com um engulho na garganta). Valdênio, dentro da forma-prisăo, é prisioneiro e acusado, exposto a um diálogo-interrogátorio cumprindo uma pena-suplício. As perguntas que lhe sâo dirigidas se constituem em armadilhas ou um campo minado, em que é constantemente testado a atravessar. Ele está sendo caçado por Melquíades também no território da linguagem e năo só quando o administrador coloca os presos para correr e fugir de seu tiro.

Sobre essa recursividade na fala do administrador, temos que notar que, quando Melquíades começa a sua "caçada" aos presos, sempre reproduz o mesmo discurso:

\footnotetext{
- Vocês săo homens quase livres, agora. Só vou falar uma vez, entăo prestem atençăo: vocês têm a chance de sair de entre os muros, mas é só uma chance, que eu considero remota. - Ergue um cronômetro. - Quando eu der o sinal, vou cronometrar trinta segundos, e nesse tempo vocês podem correr para o mais longe que conseguirem. Mas seu eu e o meu rifle CZ.22 fabricado na Tchecoslováquia e de longo alcance encontrarmos vocês, nunca mais deixarăo este lugar, entenderam? Evidente que nunca ninguém conseguiu escapar, e todos permanecem aqui, para todo o sempre.É uma medida socioeducativa. (MAIA, 2020, p.57)
}

Com pequenas diferenças, essa fala é repetida no momento em que Melquíades caça os presos Pablo e Jota. Quem leu Ensaio sobre a cegueira, de José Saramago, ou 
1984, de George Orwell, viu que a repetiçăo da linguagem está associada ao controle e regulamentaçăo de aparelhos repressivos. George Orwell, por exemplo, fala-nos até da Novafala, uma língua criada para substituir a Velhafala, numa tentativa de expurgar qualquer pensamento subversivo e mais individualizado dentro da sociedade gerida pelo Grande Irmáo. Vejamos o diálogo entre os personagens Syme e Winston sobre a Novafala:

\begin{abstract}
"Você năo sente muito admiraçăo pela Novafala, Winston", disse ele, quase triste. "Até mesmo quando escreve, continua pensando em Velhafala. Li alguns daqueles artigos que você publica no Times de vez em quando. Săo muito bons, mas săo traduçôes. No fundo você preferiria continuar usando a Velhafala, com todas as suas inexatidóes e nuances inúteis de significado. Nâo compreende a beleza da destruiçấo de palavras. Você sabia que a Novafala é a única língua do mundo cujo vocabulário encolhe a cada ano? (ORWELL, 2009, p. 68)
\end{abstract}

No contemporâneo, a Novafala equivaleria aos protocolos linguísticos que vemos em muitas canais de comunicaçóes e midias conservadoras ou liberais que se movimentam a partir de certas ideias consensuais. Dentre esses protocolos, que văo desde a mensagem em si até a própria inversăo ou invençâo de palavras, temos, por exemplo, a expressăo fake news que se encontra disseminada na sociedade contemporânea. A notícia classificada como fake news é modulada pela expressăo em inglês, retirando o julgamento moral ou mesmo jurídico da informaçáo veiculada. A velocidade, o sensacionalismo, as guerras ideológicas das notícias, certamente, contribuem para o fortalecimento das fake news, mas a questăo que queremos apontar aqui é que, como uma novafala, as fake news têm o poder de silenciar o dissenso, tal como Raciére (1996) o pensa, condiçăo fundamental para a democracia.

Chama-nos atençâo, portanto, que a efetividade do aparelho repressivo está intimamente relacionada ao conteúdo das mensagens, mas também a sua forma de elaboraçăo. Nesse sentido, a repetiçăo presente na fala de Melquíades é muito reveladora năo só da linguagem burguesa, vazia de experiência (BENJAMIN, 2011), mas sobretudo porque é um sintoma de que, reproduzida infinitamente, ganha status de verdade e retira da vida o inédito, inaugural e a divergência. Assim, Melquíades acredita que sua "medida socioeducativa" serve para fomentar a prisăo-modelo porque, a partir dela, ninguém deixará aquele lugar.

Vejamos um outro preso, Bronco Gil, refletindo sobre como os presos percebem Melquíades:

Năo se sabe há quanto tempo Melquíades caça os presos, aplicando o que chama de medida socioeducativa, mas, de acordo com Taborda, o chefe enlouqueceu nos últimos meses por causa do confinamento, do estado de isolamento e da convivência com a maldade de cada homem deste lugar. (...) Ele jamais poderia viver em sociedade novamente, foi corroído pelo sistema que defende. (MAIA, 2015, p.68)

Na explicaçăo de Bronco Gil, vemos a descriçâo de que Melquíades teria sido corroído pelo sistema que defende. Melquíades, como uma ruína, mostra que ali mesmo onde o projeto de encarceramento se faz mais presente, mais se reafirma a gestâo da morte. Ser corroído pelo sistema equivale ao funcionamento exemplar e năo ao funcionamento disruptivo. Um funcionamento tăo pleno dessa máquina de guerra só pode 
levar à exaustăo da máquina que, dessa forma, estaria disposta até a própria aniquilaçăo. Melquíades năo é uma exceçâo, como a leitura da sua loucura poderia sugerir; ele é um funcionamento tăo pleno da necropolítica que leva a sua própria morte, como a do próprio Estado como narrativa moderna.

Nesse sentido, seria interessante refletir sobre como o filósofo Vladimir Safatle dialoga com Achile Mbembe de modo a perceber os desdobramentos do necropoder e como o seu pleno funcionamento implicaria numa implosăo dando origem ao Estado Suicidário:

Engana-se quem acredita que isto é apenas a já tradicional figura do necroestado nacional. Caminhamos para além da temática necropolítica do Estado como gestor da morte e do desaparecimento. Um Estado como o nosso năo é apenas o gestor da morte. Ele é o ator contínuo de sua própria catástrofe, ele é o cultivador de sua própria explosăo. Para ser mais preciso, ele é a mistura da administraçăo da morte de setores de sua própria populaçăo e do flerte contínuo e arriscado com sua própria destruiçăo. 0 fim da Nova República terminará em um macabro ritual de emergência de uma nova forma de violência estatal e de rituais periódicos de destruiçăo de corpos. (SAFATLE, 2020, s.p)

A necropolítica, em seu pleno funcionamento, leva o Estado ao colapso ao ponto de ele próprio poder desaparecer. Tal como a imagem de Melquíades, que se encontra corroído pelo sistema, esse Estado exposto ao necropoder náo se furtaria a também se oferecer como sacrifício do que quer salvar: o exercício do poder pura e simplesmente. No extremo, o necropoder se apresenta como um exercício de poder que pode ser confundido com uma loucura, aquilo que aparentemente gostaria de evitar como sistema disciplinar e regulatório.

A confiança cega na razáo, metaforizada no cumprimento das ordens, faz com que a prisăo se transforme num lugar de extermínio. Aqui, responde-se à pergunta de como melhorar a funcionalidade da prisăo-panóptico: a criaçăo de espaços cuja efetividade é garantida pela morte dos prisioneiros. A prisăo-modelo, portanto, como lugar de extermínio, mostra o revés catastrófico do sonho da razăo e da ordem.

Essa maneira extrema de necropolítica pode, ainda, ser observada no pai de Melquíades. Dele, o administrador herda um exemplar da Bíblia e a maneira bélica de lidar com o outro, ou seja, está dentro de um loop familiar que agencia o necropoder:

Aprendeu com o pai, um ex-policial, que o melhor lugar para se manter um bandido é debaixo da terra. Antes de ser baleado e cair de uma altura de trinta metros, fuzilou pelo menos seis. Seu nome consta nos registros dos heróis da polícia. Em casa, era fechado e quieto. Na maior parte do tempo, compungido. Gostava de ler Bíblia, e carregava consigo um pequeno exemplar, justamente como faz Melquíades, que, com esse gesto, mantém um contínuo memorial de seu pai. (MAIA, 2020, p. 80)

Quando seu pai acredita que o melhor lugar para um bandido é debaixo da terra e quando, por ter matado seis, é condecorado herói, a sociedade dá um recado para Melquíades. A forma-prisăo é uma forma-social, que encontra respaldo nessas falas e atitudes que fazem parte do pai de Melquíades e da sociedade. $O$ extremo da forma-prisăo aqui aparece no "sacrifício" do pai, a mesma morte que Melquíades náo renega. 
Mas a denúncia do texto, por vezes, é mais evidente, quando, por exemplo, mostra que, quando o pai de Melquíades se interessava pela vida, era enfermeiro; depois, quando se identificou com a morte, tornou-se policial:

Antes de entrar para a polícia, seu pai trabalhava como enfermeiro na emergência de um hospital. Lidava com sangue, mas salvava vidas. Inclusive a de bandidos. Era imparcial: o que caía em sua măo, ele se esforçava para manter vivo. Isso foi antes de Melquíades nascer. Aos poucos, a vontade de matar foi se tornando maior que a vontade de ajudar a viver. Nos plantôes da emergência era comum lidar com vítimas e criminosos ao mesmo tempo. Foi assim que, gradativamente, surgiu seu desprezo pela vida. Aflorou madrugada a madrugava. Depois de algum tempo caçar javali já năo o saciava. Queria mais. Entrou para a polícia e matou mais criminosos em um ano que javalis em toda a sua vida. Porém, mesmo sendo a escória, ainda eram seus semelhantes. E isso começou a afetá-lo. (MAIA, 2020, p. 80)

Com essa vinculaçâo das forças policiais à morte, vemos uma crítica ao aparato regulatório do Estado, que, desse ponto de vista, estaria associado ao biopoder e à necropolítica.

Essa associaçâo encontra, ainda, numa imagem a sua exemplificaçăo dentro do romance. Trata-se do momento em que Melquíades substitui o retrato do presidente da república por uma cabeça de javali. O quadro estava na sala onde Melquíades ficava e, assim que Taborda consegue terminar o trabalho de empalhar a cabeça de javali, o administrador faz essa substituiçăo:

Melquíades vira-se e olha para a foto pregada na parede. [...] Deixa a cabeça empalhada sobre a mesa e cuidadosamente retira o quadro com a foto do presidente.

[...] Entra no pequeno banheiro de sua sala e de lá fala para Taborda:

- Encontrei um lugar.

Taborda entra no banheiro, e um prego na parede acima do vaso sanitário descansa, enferrujado e inútil. (MAIA, 2020, p. 35)

Essa substituiçăo revela como, de fato, o Estado deve ser visto, descortinando todas as suas narrativas progressistas e biopolíticas: como um exercício de barbárie. A caça morta, empalhada e sem olhos no lugar do quadro do presidente é um troféu para um Estado que entende justiça como uma eliminaçấo e controle de grupos.

\section{3 É POSSÍVEL RESISTIR DENTRO DA COLÔNIA?}

Uma vez que tratamos do espaço da Colônia Penal e do agente mais efetivo das políticas da necropolítica, falta percebermos como sobreviver a esse tipo de poder. A primeira questăo nesse sentido é pensarmos que a resistência năo pode ser pensada, apenas, dentro daquele tempo messiânico da redençăo ou dentro da própria linha temporal instituída pela modernidade conhecida como tempo do progresso. A resistência às diferentes formas de poder pode também ser diversa, por isso seu sentido năo está encerrado apenas no enfrentamento direto às opressóes. Ao enfrentar uma opressăo, os diferentes sujeitos se valem de uma série de estratégias que, muitas vezes, năo está centrada em oferecer uma resposta com a mesma intensidade da pergunta que foi 
dirigida. Na linguagem, há vários mecanismos que podem produzir um movimento de deflaxăo, em que observamos um grau de deslocamento proporcionado pela carga que é dispensada sobre um objeto.

Sabendo disso, dois presos săo importantes em termos de como responder à opressăo: Valdênio e Bronco Gil. O primeiro é um dos mais velhos da colônia, e o segundo, um dos últimos a chegar. Além disso, os dois apresentam no corpo a marca de algum tipo de violência: Valdênio, de tanto apanhar nas diferentes prisōes por onde passou, ficou manco de uma perna, e Bronco Gil perdeu um olho comido por um urubu. Se Melquíades é descrito como corroído pelo sistema, os presos também mostram no corpo a corrosáo por algum tipo de violência, mas, diferente do administrador, que é pura alienaçăo, os dois, mesmo afetados pela Colônia, conseguem, de modos distintos, desenvolver estratégias de sobrevivência.

Sobre Valdênio já vimos, na primeira parte, como ele desliza por entre as manobras de interrogatório de Melquíades. Consegue ser um dos últimos sobreviventes da Colônia e, assim como todos, acredita que a tornozoleira que tem no pé explodirá caso fuja da prisâo. Está preso na forma-prisăo que faz a manutençăo do medo da explosăo da perna. Mas é interessante como Valdênio tem consciência de que a prisăo é uma encenaçâo da justiça, por isso, quando Pablo, um preso que consegue escapar da caçada de Melquíades, informa que fugirá dali e salvará a todos porque denunciará o que acontece dentro da Colônia, Valdênio pede que ele năo faça isso.

Esse tipo de postura denuncia que Valdênio sabe que a Colônia é uma forma-prisăo e, como tal, nâo é uma excrecência, mas algo aceito pela sociedade, portanto năo faria sentido se arriscar em denunciar. Entretanto, essa consciência nâo implica que, no final da narrativa, Valdênio nâo se arrisque a sair da Colônia mesmo com a tornozeleira. Numa conversa com Bronco Gil, vemos Valdênio assumindo o risco de morrer a ficar na Colônia:

\footnotetext{
- Sempre quis saber se esta coisa explode de verdade. Nunca te contei, mas tive uma chance de sair daqui. Uma única vez. Eu poderia ter ido pra longe e nunca mais me encontrariam, mas tive medo desta coisa explodir. Năo me importo mais.

Valdênio dá o primeiro passo para fora dos muros. Respira fundo e dá mais dez passos até parar. Vira-se para Bronco Gil, que permanece do lado de dentro da esperança do porvir. Contam, cada um para si, até trinta. Nada acontece. Valdênio bate as palmas e dá um pequeno pulo.

- Eu sempre desconfiei, índio. Eles mentiram pra nós esse tempo todo. A gente se cagando de medo e podia simplesmente ter ido embora. - Cai na gargalhada com nunca antes. (MAIA, 2020, p. 131)
}

Valdênio toma essa atitude logo depois de uma série de eventos que apontam para o fim da Colônia e quando só restam ele e Bronco Gil como prisioneiros. Portanto, é só nesse momento que se sente confortável a arriscar a própria vida e superar o medo de explodir a própria perna. A tornozeleira náo explode a despeito do que os agentes penitenciários diziam. $\mathrm{O}$ medo da explosâo paralisava todos os presos, funcionando como uma mecanismo de controle de todos ali. Assim, entre os aparatos disciplinares que compóem o poder, o medo é um importante aliado. Valdênio só consegue superá-lo numa conjuntura que é completamente diferente do começo a narrativa. Por isso, sua resposta à opressáo é construída e estudada. 
Sobre o medo, vemos que o Estado moderno capturou esse sentimento e o administrou criando uma rede de proteçáo conhecido como Estado social. De acordo com Bauman, houve uma substituiçăo de elementos naturais de solidariedade, como a vizinhança ou laços comunitários, por vínculos artificiais como "associaçōes, sindicatos, coletividades de tempo parcial". (BAUMAN, 2007, p.73). Estaríamos, de acordo com o filósofo, atravessando uma fase de desintegraçâo desses elementos que administraram o medo, pressionado por forças globais de mercado:

Essa segunda desregulamentaçăo năo foi seguida, contudo, de novas formas sociais de administraçăo do medo. A tarefa de enfrentar os temores decorrentes das novas incertezas tem sido, da mesma forma que os próprios medos, desregulamentada e "terceirizada", ou seja, deixada aos esforços e iniciativas locais, e em grande parte privatizada - transferida, em larga medida, para a esfera da "política de vida", ou seja, deixada amplamente aos cuidados, engenhosidade e astúcia de indivíduos, assim como aos mercados, que năo aceitam e eficazmente rejeitam todas as formas de interferência comunal (política), para náo falar de controle. (BAUMAN, 2007, p. 74)

Essa terceirizaçâo do sentimento significa deixar os indivíduos na administraçăo dos seus própr ios medos. Na sociedade, faz emergir a condiçăo de classes perigosas permanentemente e esses grupos se verăo desamparados pelo Estado em termo de administraçáo de suas vulnerabilidades.

O medo de a perna explodir pela tornozeleira, que paralisa os presos, năo está relacionada apenas à morte, mas também a uma impotência, algo que demonstra a condiçâo deles: é como se todos estivessem com uma bomba amarrada ao próprio corpo prestes a explodir. Essa condiçăo é proporcionada pela situaçăo desses grupos num Estado que abdicou de ser um Estado social:

Tal como as pessoas sem emprego, os criminosos (ou seja, aqueles destinados à prisăo, acusados e aguardando julgamento, sob supervisăo da polícia ou simplesmente com ficha na polícia) náo săo mais vistos como temporariamente expulsos da vida social normal e destinados a serem "reeducados", "reabilitados" e "reenviados à comunidade" na primeira oportunidade - mas como permanentemente marginalizados, inadequados para a "reciclagem social" e designados a serem mantidos permanentemente fora, longe da comunidade dos cidadăos cumpridores da lei (BAUMAN, 2007, p. 76)

Em Bronco Gil, encontramos uma outra manei ra de lidar com a opressăo. Filho de uma indígena que foi estuprada por um fazendeiro, Bronco Gil é chamado de índio pelos agentes da colônia. Está sempre atento aos movimentos dentro da Colônia e consegue fugir fazendo um acordo com Heitor, o agente da justiça que chega ali para fechar o lugar. O acordo com um representante do poder é que, se Bronco Gil matasse Melquíades (que, naquele momento, estava ameaçando a vida dos dois), ficaria livre da prisăo. Portanto, năo é um trato muito distinto daquele que o próprio Bronco Gil fizera e pelo qual estava pagando na prisáo, uma vez que estava ali porque tinha matado por encomenda um prefeito.

Quando o sistema precisa de alguém para eliminar algo indesejado, se serve daqueles cujos crimes sâo punidos por fazerem justamente o que é pedido, nos mostrando que a justiça tem muito mais a ver com o que o poder pensa do que um conjunto de regras que năo podem ser rompidas. Esse comportamento volúvel e parcial da justiça 
serve para denunciar a sua arbitrariedade, deixando à mostra que é, simplesmente, um exercício do poder:

Aos pés de Heitor, joga o corpo do agente. [...]

- Serviço limpo - diz Bronco.

Heitor olha para o corpo com ânsia de vômito. [...]

- Agora o nosso acordo - diz.

Heitor abaixa-se e remove a tornozeleira de Bronco Gil. (MAIA, 2020, pp. 139 -140)

Para impedir o inevitável comportamento do agente, porque, como acreditamos, Melquíades é para onde converge a próprio discurso da necropolítica, Heitor dá status de legitimidade àquilo que o sistema condena. Esse capricho da justiça mostra como ela é um dispositivo que faz a manutençâo do poder gerindo as mortes. As mortes só săo injustas, portanto passíveis de penas, se estiverem fora dos cálculos do poder. Atravessado pelo racismo e pelo fascismo, esse poder só ganha legitimidade, portanto só é visto como justo, quando inclui dentro dos seus cálculos da morte os grupos mais vulneráveis.

Sobre esses grupos, a narrativa nos mostra que náo só na terra, como embaixo dela eles năo estăo a salvo, uma situaçăo que se mantém ao longo do tempo. O conflito está em todos os lugares, verticalizado no subsolo e estendido no tempo. Ao ouvirmos o histórico da Colônia, sabemos que ali era um lugar chamado de Calvário Negro, para onde se levavam os negros escravizados para serem mortos. Quando os presos vấo enterrar os corpos dos companheiros mortos por Melquíades, encontram vários esqueletos que remontam a esse passado, mas uma descoberta em particular choca a todos: um baú cheio de restos mortais de crianças. É o agente Taborda que revela isso para Heitor: “- Abrimos o baú e quis acreditar que eram animais. Mas eram bebês. Bebezinhos. Os ossos bem pequenos tăo frágeis, eram muitos..." (MAIA, 2020, p. 124)

Esse histórico de morte da colônia à Colônia Penal nos demonstra a manutençâo de práticas de poder, embora o país já náo esteja no colonialismo histórico. Faz-nos pensar numa naçáo que, embora esteja assentada no pacto de direitos e deveres igualitários aos seus cidadāos e numa economia que fomenta a liberdade para seus sujeitos, mantém uma dinâmica social muito excludente. Esse tipo de dinâmica, como forma social, está presente em todas as instituiçôes do Estado, se constituindo mais numa condiçâo de existência do que numa exceçăo. Os aparatos institucionais do Estado, portanto, garantem o controle e a exclusăo ao mesmo tempo, mas, revestidos de narrativas progressistas e neoliberais, sâo vistos apenas como bens emancipadores ou como aqueles que protegerăo a propriedade privada e a liberdade individual. Desse ponto de vista, o sistema penal, como o romance discute, é um instrumento de controle visando à manutençăo e reproduçăo do pensamento hegemônico sobre o que é uma sociedade; năo visa correçâo, tampouco alguma transformaçăo:

Finalmente Valdênio está do lado de fora e olha para o interior da Colônia pela primeira vez. (...) Acima do portăo, em letras de ferro desgastado, está escrito há muito tempo: "A correçáo nos torna livres". (...)

- Que maldiçăo, velho? O que tem aí? - Bronco Gil lê a inscriçáo. - Deixa disso, velho. Eles corrigem a gente com uma bala na cabeça, e somos livres quando morremos. É isso o que diz aí em cima. No fim, somos todos livres, porque, no fim, estaremos mortos. (MAIA, 2020, pp. 131-132) 
Na citaçâo acima, a frase encontrada no portăo da Colônia Penal ("A correçáo nos torna livres") se assemelha a uma inscriçăo muito cara para a história ocidental. Tratase da expressâo encontrada em vários campos de concentraçăo nazista: Arbeit macht frei (O trabalho liberta). O jogo entre a inscriçăo do portăo da Colônia Penal com a frase que aciona um dos episódios mais trágicos da história pontua a ironia e crítica do romance de Ana Paula Maia à noçấo de correçăo como libertaçăo.

Os cadáveres que podem ser encontrados por toda a Colônia remontam a essa ideia de correçấo que persiste no tempo e no espaço. Mas fazem-nos entender que, a despeito de uma sociedade que desenvolve políticas de esquecimento da violência, essa memória deve estar sempre presente sob pena da sua repetiçâo.

Umberto Eco, na obra $\mathrm{O}$ fascismo eterno, cita no final do texto um poema de Franco Fortini para argumentar que "Liberdade e libertaçăo săo uma tarefa que năo acaba nunca (ECO, 2018, p.61). No poema, encontramos também as lembranças da violência por todos os lugares, numa forma de lembrar que o fascismo está sempre à espreita:

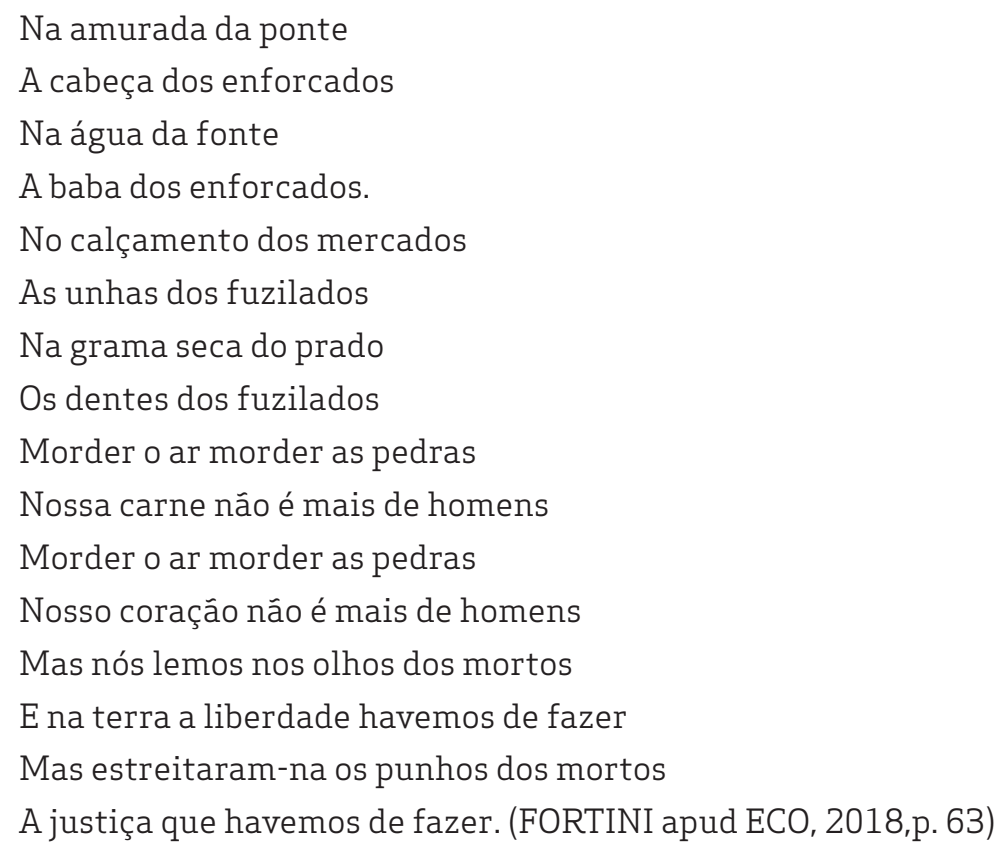

A sociedade é excludente, acumulativa e exploratória e prega a crença nas mitologias progressistas e emancipatórias impedindo-nos que vejamos seus dispositivos regulatórios como órgáos de controle e políticas da morte. O romance de Ana Paula Maia permite a desnaturalizaçấo dessa ideia para uma justiça para os que estăo na terra como embaixo dela.

\section{CONCLUSÃO}

O romance Assim na terra com embaixo da terra discute a relaçăo entre sociedade, Estado, grupos vulneráveis e sistema penal. A partir de uma história aparentemente extrema numa Colônia Penal onde os prisioneiros săo mortos, a obra possibilita pensar no nosso contemporâneo em que práticas necropolíticas e suicidárias fazem parte do discurso do Estado. 
Observamos no estudo da forma-social prisâo como a crença na correçấo como promoçâo do homem livre legitima a morte de alguns grupos. Atravessada pelo racismo e pelo fascismo, nossa sociedade se apoia em dispositivos paradoxais que só conseguem ser vistos como tais se o colocamos à prova, como o romance o faz.

Assim, a situaçấo dos presos no romance só é descabida dentro de uma retórica humanista que acredita que o biopoder, realmente, é pensado como política de promoçăo da vida sem ser atravessado por lógicas de mercado e coloniais. Se năo considerarmos essas outras forças que atravessam o biopoder, nâo conseguiremos observá-lo de maneira crítica.

Nesse sentido, ressalta-se a importância da luta ao longo do tempo e nesse espaço de políticas verticais. Se há conflito por todas as dimensóes dentro de uma sociedade que aceita a forma-prisâo, há igualmente memória desse conflito. Os corpos nos subsolos e a fuga espetacular de poucos prisioneiros mostram que, assim na terra como embaixo da terra, há a vida tentando resistir a formas de opressăo que resistem no tempo e nos espaços. 


\section{REFERÊNCIAS}

ALEXANDER, Michelle. A nova segregaçăo; racismo e encarceramento em massa. Trad. Pedro Davolglio. Săo Paulo: Boitempo, 2017.

BENJAMIN, Walter. Sobre a linguagem em geral e sobre a linguagem do homem. In: BENJAMIN, Walter. Escritos sobre mito e linguagem (1915-1921). Trad. Susana Kampff Lages e Ernani Chaves. Sáo Paulo: Livraria Duas Cidades, Editora 34, 2011.

BAUMAN, Zygmunt. Tempos líquidos. Trad. Carlos Alberto Medeiros. Rio de janeiro: Zahar, 2007

ECO, Umberto. O fascismo eterno. Trad. Eliana Aguiar. Rio de Janeiro, Săo Paulo: Record, 2018.

FOUCAULT, Michel. Em defesa da sociedade. Sâo Paulo: Martins Fontes, 2005.

FOUCAULT, Michel. A sociedade punitiva. Trad. Ivone C. Benedetti. Săo Paulo: Martins Fontes, 2015.

GRUPO DE TRABALHO COVID-19 DA UNIVERSIDADE FEDERAL DE MINAS GERAIS. Isolamento social vertical é ineficaz para conter a pandemia COVID-19 (coronavírus). 5 de abril de 2020. Disponível em: https://drive.google.com/file/d/126YvM4ornYByit3jKQaeZjLMNEsuuYbs/view Acesso em 17/04/2020.

MAIA, Ana Paula. Assim na terra como embaixo da terra. Rio de janeiro, Sáo Paulo: Record, 2020.

GRÜNNAGELL, Christian. "Ir aonde ninguém quer ir": entrevista com Ana Paula Maia. Estudos de literatura brasileira contemporânea. n. 45, pp. 351-371, jan./jun. 2015. Disponível em: http://www.scielo.br/pdf/elbc/n45/2316-4018-elbc-45-00351.pdf Acesso em 19/04/2020.

MBEMBE, Achille. Necropolítica. Săo Paulo: N-1 ediçôes, 2018.

MEMMI, Albert. Retrato do colonizado precedido pelo retrato do colonizador. Trad. Roland Corbisier e Mariza Pinto. 2 ed. Rio de Janeiro: Paz e Terra, 1977.

ORWELL, George. 1984. Trad. Alexandre Hubner e Heloisa Jahn. Săo Paulo: Companhia das Letras, 2009.

RANCIÉRE, Jacques. O dissenso. In: NOVAES, Adauto (org.) A crise da razăo. Trad. Paulo Neves. Săo Paulo: Companhia das Letras,1996.

SAFATLE, Vladimir. Bem-vindo ao Estado suicidário. Disponível em: https://n-1edicoes. org/004 Acesso em 14/04/2020.

Recebido em 12/05/2020

Aceito em 21/06/2020 